Volume 27 Issue 1, Januari 2020: pp. 1-22 Copyright (C) 2020 Jurnal Hukum lus Quia lustum Faculty of Law, Universitas Islam Indonesia. ISSN 0854-8498 I e-ISSN: 2527-502X.

Open access at: http://jurnal.uii.ac.id/indek.php/IUSTUM

JH lus Quia lustum is licensed under a Creative Commons Attribution 4.0 International License. Which Permits unrestricted use, distrubution, and reproduction in any medium, provided the original work is properly cited

\title{
The Implementation Of The First Pillar Of Responsibility To Protect In Indonesia: Critical Analysis Of Law On Social Conflict Management
}

\author{
Sefriani \\ Fakultas Hukum Universitas Islam Indonesia \\ Jln. Tamansiswa No. 158 Yogyakarta \\ sefriani@uii.ac.id
}

Received: 17 Juni 2019; Accepted: 27 Januari 2020; Published: 29 Juni 2020

DOI: 10.20885/iustum.vol27.iss1.art1

\begin{abstract}
Responsibility to Protect Principle (R2P) is intended to accomplish the humanitarian intervention principle which considered has a failure in many aspects. However, the existence of this principle still leaves worry, especially for a developing country, over manipulation and politics in its implementation. The formulated problems for this research are (1) how is the development of the R2P principle in International Law? (2) how is the implementation of the first pillar of R2P to prevent mass atrocities crime in the Indonesian government? The result shows that R2P gained more supports and was adopted in General Assembly resolution, completed with three pillars and six thresholds for its implementation. The implementation of the first pillar of R2P in Indonesia as a state responsibility to protect the society from mass atrocities crime has not been conducted properly. Although Indonesia already had a law on social conflict management, however, minimum law enforcement arrangement; high impunity culture, lack of knowledge about R2P, revocation of law on CTR, the impartiality of governmenttowards some majority groups potentially make the implementation of the first pillar of R2P in Indonesia will be failed.
\end{abstract}

Keywords: Intervention; law enforcement; mass atrocities crime; R2P; social conflict

\section{Abstrak}

Prinsip Kewajiban untuk Melindungi (Responsibility to Protect Principle, R2P) dimaksudkan untuk mencapai prinsip intervensi kemanusiaan (humanitarian intervention) yang dianggap memiliki kegagalan dalam banyak aspek. Namun, keberadaan prinsip ini masih menyisakan kekhawatiran, terutama bagi negara berkembang, atas manipulasi dan politik dalam implementasinya. Masalah yang dirumuskan untuk penelitian ini adalah, Pertama, bagaimana pengembangan prinsip R2P dalam Hukum Internasional? Kedua, bagaimana implementasi pilar pertama R2P untuk mencegah kejahatan kekejaman massal dalam pemerintah Indonesia? Hasilnya menunjukkan bahwa R2P mendapatkan lebih banyak dukungan dan diadopsi dalam resolusi Majelis Umum, dilengkapi dengan tiga pilar dan enam ambang batas untuk implementasinya. Implementasi pilar pertama R2P di Indonesia sebagai tanggung jawab negara untuk melindungi masyarakat dari kejahatan kekejaman massal belum dilakukan dengan baik. Meskipun Indonesia sudah memiliki Undang-Undang tentang manajemen konflik sosial, namun, pengaturan penegakan hukum yang rendah; budaya impunitas tinggi, kurangnya pengetahuan tentang R2P, pencabutan Undang-Undang tentang RKPT, dan ketidakberpihakan pemerintah terhadap beberapa kelompok mayoritas berpotensi membuat implementasi pilar R2P pertama di Indonesia gagal.

Kata-kata Kunci: Intervensi; kejahatan kekejaman massal; konflik sosial; penegakan hukum; R2P 


\section{Introduction}

The notion of Responsibility to Protect (R2P) has appeared since the 1990s as a response to the failure of international society to prevent a humanitarian crisis in Rwanda, Bosnia, and other places. ${ }^{1}$ The early concept of R2P had been delivered by Francis Deng, the representative member of the United Nations for Internal Refugee Problem. According to Deng, the sovereignty of a state is not the state's right to conduct anything according to its wishes without any international involvement, but state sovereignty has to be pledged based on the protection for its people who live in its area. State sovereignty must be built based on sovereignty as a responsibility concept. ${ }^{2}$

Furthermore, the R2P concept also rises as a response to the failure of the humanitarian intervention principle, which existed first. ${ }^{3}$ Humanitarian intervention is often considered failed to overcome various humanitarian crises because there is a conflict of interest among the developed countries. Although gaining mandate based onthe United Nations (UN) Security Council Resolution number 1973, a humanitarian intervention conducted by NATO in Lybia through the Fajar Odyssey operation violated many principles of international laws. ${ }^{4}$ This fact makes humanitarian intervention is considered as developed countries' arrogance against developing countries. ${ }^{5}$

In 2009, Ban Ki-Moon compiles report entitled "Implementing the Responsibility to Protect", 6 which consist of three pillars to implement R2P principle:7

${ }^{1}$ Mainstreaming the Responsibility to Protect Southeast Asia: Pathway toward Caring ASEAN Community, Report of the High Level Advisory Panel on the Responsibility to Protect in Southeast Asia, Presented at the United Nations, New York, September 9 ${ }^{\text {th }}, 2014$, p. 7

${ }^{2}$ Responsibility to Protect: Informasitentang Prinsipinidan Langkah-langkah Implementasi last visited 3 September 2017 available at http://www.responsibilitytoprotect.org/R2P basic info Bahasa.pdf, p. 2

${ }^{3}$ Bebeb A.K. Djundjunandan Rizal Wirakara, "The Responsibility to Protect Dalam Perspektif Hukum”, Opinion juris, Volume 01, Oktober 2009, p. 4

${ }^{4}$ Rahayu, "Eksistensiprinsip Responsibility to protect dalam Hukum Internasional", article in Upgrading Recent Issues of International Law doctrine, held by association of lecturer of international law cooperate with law faculty, Universitas Diponegoro, Semarang, 20-21 Mei 2011, p. 1

5 Thomas M Franck, "International Change in the Law of Humanitarian Intervention" in JL Hobzgrefe\& Robert O Keohane (eds), Humanitarian Intervention: Ethical, Legal and Political Dilemmas, University Press, Cambridge, 2003, p. 204-231

${ }^{6}$ U.N. Secretary-General, Implementing the Responsibility to Protect: Rep. of the Secretary-General, P 2, U.N. Doc. A/63/677, Jan, 12, 2009

${ }^{7}$ Responsibility to Protect. Informasitentang Prinsipinidan Langkah-langkah Implementasi, last visited 3 September 2017 at http://www.responsibilitytoprotect.org/R2P basic info Bahasa.pdf, p.3 
1. The state responsibility to protect its people from genocide, war crimes, ethnic cleansing, a crime against humanity, and any kind of act which leads to these crimes. ${ }^{8}$ The aim of the first pillar is to guarantee that the state protects its people from Mass Atrocity Crimes.

2. The commitment of the international community to help other statesin performing its responsibility to overcome humanitarian crises in its territory. ${ }^{9}$ The aim of the second pillar is to create joined commitment and an active partnership between the international society and state. The joined forces can be done secretly or openly, and also in a form of training, education, assistance, mediation, and/or dialog. 10

3. Responsibility from every UN member to respond collectively on time and assertively when a state fails to give the protection needed.

The implementation of the first pillar of R2P is very crucial to be conducted by any state to prevent humanitarian intervention applied by international society because the state is considered incapable or unwilling to protect its people from mass atrocities crimes which raise humanitarian crisis in its territory. The adequate implementation of the first pillar can prevent mass atrocities crime. Mass atrocities crime is usually started by a social conflict that grows into violence, widespread, and then mass atrocities crime becomes its peak. Social conflict can be triggered by injustice, poverty, social jealousy, and intolerance towards religion, race, customs, culture, and others.11 Many studies had proven that a country consisting several of tribes, ethnicities, religions, and ideologies, which sealed by rigid class boundaries, has a big potential for conflict if those differences and gaps are not well-maintained. ${ }^{12}$ Therefore, conflict study becomes the main issue in Indonesia through various events of violence either in ethnicity, religion, and separatism. ${ }^{13}$

Some widespread social conflicts become atrocities crime and seize public attention in Indonesia, such as the suspected massacre of hundreds of people

\footnotetext{
${ }^{8}$ David Scheffer, "Atrocities Crimes Framing the Responsibility to Protect", 40 Case W. Res. J. Int'l L. 111, 2007-2008, p. 111

${ }^{9}$ The four of crimes called as mass atrocities crimes

${ }^{10}$ Michael Small, "An Analysis of the responsibility to Protect Program in Light of the Conflict in Syria", 13 Wash. U. Global Stud. L. Rev. 179, 2014, p. 183

11 St. Aisyah BM, "KonflikSosial Dalam Hubungan Antar Umat Beragama”, Jurnal Dakwah Tabligh, Vol. 15, No. 2, December 2014, 189 - 208, p. 203

12 See, Susetiawan, Konflik. Sosial, Kajian Sosiologis Hubungan Burub, Perusabaan dan Negara di Indonesia, Pustaka Pelajar, Yogyakarta, 2000

${ }^{13}$ Susan, N, Sosiologi Konflik dan Isu -Isu Konflik Kontemporer, Prenada Media Group, Jakarta, p. 5
} 
which isconducted by the Communist Party of Indonesia (CPI) in 1965-1966,14 Malari conflict, Tanjung Priok conflict, separatist movement in Aceh, Papua, and Timor Timur, and also riots accompanying the fall of Soeharto in 1997-1998.

Although humanitarian intervention has never been applied in Indonesia, however, if there is similar social violence occurred, the chance of humanitarian intervention applied may be susceptible. Moreover, the tolerance in the society is decreasing and easily ignited by provocative news full of resentment content, which deliberately made by certain parties to cause state instability. This is the reason why the implementation of the first pillar of R2P is very important to be done as a preventive act of humanitarian intervention implementation in Indonesia.

This study focuses on the first pillar of R2P only to limit the scope of the discussion. The choice of the first pillar due to there are still rarely writings on R2P that raise the issue of the first pillar. Most of the R2P writings focused on the third pillar concerning humanitarian intervention. Another reason for choosing implementation of the first pillar is because the first pillar which contains the responsibility of State to protect its citizens is actually in accordance with the mandate of the 1945 Indonesian constitution, stipulated in paragraph 4, the preamble of 1945 Indonesia constitution as follow:..." that Pursuant to which, in order to form a Government of the State of Indonesia that shall protect the whole people of Indonesia and the entire homeland of Indonesia...".

\section{Problems Statement}

Based on the aforementioned introduction, there is two problems statement, they are: first, how is the development of R2P in international law? And second, how is the first pillar ofR2P implemented by the Indonesian Government?

\footnotetext{
${ }^{14}$ Estimated number of victims in the rebellion of Indonesian Communist Party 1965 around 500,000 to 600,000 people, see Sulistyo, Hermawan, PaluArit in Sugar Cane: History of the forgotten massacre, Jombang-Kediri 196566, Gramedia, Jakarta, 2000. See also Mohammad Zulfan Tadjoeddi, "Anatomy of Social Violence in the Transition Context: Case of Indonesia, 1990-2001”, working paper: 02 / 01-1, United Nations Support Facility for Indonesian Recovery (UNSFIR),2002, p. 33, accessed last 12 September 2017 at http://www.conflictrecovery.org/bin/Zulfan-Anatomi_kekerasan_sosial.pdf
} 


\section{Objective Research}

This research is intended to analyze the development of R2P in international law and the implementation of the first pillar of R2P by the Indonesian Government in-depth.

\section{Research Methods}

This research isnormative legal research which usesa conceptual, historical, and comparative approach. The result of this study is presented in descriptiveanalytic.

\section{Reseach and Analysis}

\section{Development of R2P in International Law}

\section{Chronology of R2P in international Law}

During 1990-1994, the Security Council of United Nations issued twice as many resolutions in the history of the United Nations' long journey ${ }^{15}$ as a response against threat towards international peace based on Chapter VII of the United Nations Charter which widens prior to humanity's problem. ${ }^{16}$ In decades after the Cold War, the Security Council of the United Nations issued a resolution about humanitarian intervention underChapter VII in the cases of Somalia, Liberia, Rwanda, Haiti, Sierra Leone, and Kosovo.

The pros and cons of humanitarian intervention usually arise from the existence of the Security Council's authorization. ${ }^{17}$ Kofi Annan in his speech stated that the state's sovereignty should no longer be used as a shield to violate the basic human right to its people. ${ }^{18}$ There is no single principle in law that allows sovereignty as a shield for humanitarian violence. ${ }^{19}$

15 Rebecca J. Hamilton, “The Responsibility to Protect: From Document to Doctrine-But What of Implementation?,19 Harv. Hum. Rts. J. 289,2006, p. 289

16 Alex J. Bellamy, "Responsibility to Protect or Trojan Horse? The Crisis in Darfur and Humanitarian Intervention After Iraq", Ethics \& Int'L Aff, Summer, 31, 2005, p. 34. See also, Martti Koskenniemi, “The Police in the Temple Order, Justice, and the UN: A Dialectical View", 6 Eur. J. Int'L law 1, 1995, p. 2-7

${ }^{17}$ Muladi, "Hakekat Norma R2P atau Responsibility to Protect dan Ambang Batas Justifikasinya", article on Upgrading Recent Issues of International Law doctrine, held by Association of lecturer of international law cooperate with faculty of law, Universitas Diponegoro, Semarang, 20-21 May, 2011, p. 4

18 Nadia Banteka, "Dangerous Liaisons: responsibility to Protect and reform of The Un Security Council”, 54 Colum. J. Transnat'l L, 382, 2016, p. 388

${ }^{19}$ Michael Small, supra no. 13, at. 180 
In 2005, the United Nations held a World Summit. ${ }^{20}$ The result of the World Summit was documented in The Summit Outcome Document 2005. There are two important main points which must be highlighted from paragraph 139 of the summit outcome document: ${ }^{21}$ a. Summit Outcome only admits a peaceful method to conduct R2P; b. Summit Outcome ignores any interpretation of unilateral acts or military intervention and abolishes the absolute concept of state sovereignty.

Mehrdad Payandeh records that the Summit Outcome does not acknowledge the special responsibility of the Security Council, does not mention the possibility of unilateral or collective action on behalf of the General Assembly, and declinesthe criteria arrangement which needed to authorize the exercise of violence.22 However, it turns out that the Summit Outcome was not directly adopted. There were many debates and critics towards this document. Responding to this issue, Ban Kin Moon in 2009 stated a report entitled Implementing R2P which consisting of three pillars of guidance for the implementation of R2P. ${ }^{23}$

In its progress, R2P gains much more support from the international society. The General Assembly of United Nations finally adopts G.A. Res. 63/308 which reconfirmed the principles of the United Nations, the importance of prevention towards serious crime, and the responsibility of international society to hold state's accountability for committing such offenses. However, adopting the resolution does not directly create the R2P law and does not make it a legally binding norm tointernational society. Its status as a legal principle must be regarded. ${ }^{24}$ According to Muladi, R2P is not a law, but it is a norm or a set of principles which based on thought that sovereignty is actually not only a special right but also a responsibility to protect the people from mass atrocities;

\footnotetext{
${ }^{20}$ Responsibility to Protect. last visited, 3 September 2017 at:http://www.responsibilitytoprotect.org/

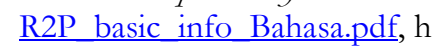

${ }^{21}$ Michael Small, supra no. 31, at. 181

${ }^{22}$ Mehrdad Payandeh, "With Great Power Comes Great Responsibility? The Concept of the Responsibility to Protect Within the Process of International Lawmaking”, 35 Yale J. Int'l L. 469, 2010, p. 476

23 See discussion on p. 2-3 of this article

${ }^{24}$ Aidan Hehir, "The Responsibility to Protect and International Law", in Philip Cunliffe (ed.), Critical Perspectives on the Responsibility to Protect: Interrogating Theory, Practice, Martinus Nijhoff, 2011, p. 27
} 
responsibility of the international society to provide international assistance and capacity building, also responsibility to interfere, which is the very last resort. ${ }^{25}$

The framework of R2P from ICISS indeed has already given the most comprehensive approach towards humanitarian intervention compare to others. It also has given the framework for the implementation of the intervention from diplomatic sanction, economy, up tomilitary intervention as the last alternative. ${ }^{26}$ R2P gives a set of clear guidelines or clearer code of conduct to determine when and how an intervention is done, which covers the stage of "to prevent, to react, and to build".27 Moreover, according to ICISS, the justification of military operation in the implementation of R2P must comply with the threshold that military invasion should be based on:28

a. just cause is a courteous reason. It has to be proven by an extraordinary level of human suffering, loss of lives in massive scale, which is usually called genocide or ethnic cleansing which can be done by forced evictions, terror, or rape, ${ }^{29}$ either being done the state directly or even because of the failure of the state to stop it. ${ }^{30}$

b. right intension isthe right course that the intervention is being done for one specific reason, which is to prevent or stop human suffering.

c. the final resort is the last stage that is being reinforced because all of the peace methods proposed, either through diplomacy or non-military, have failed.

d. legitimate authority is the legitimacy of authority from the Security Council of the United Nations, can be obtained directly from them or asked the Secretary-General to conduct the authority under article 99 UN Charter. If the authorization fails to be obtained, there are other two alternatives. The first alternative is through the United Nations General Assembly, who conduct emergency session-based "Uniting for Peace" procedure and gaining $2 / 3$ affirmative votes from all the United Nations' member. The second alternative is through a regional organization to get authorization from the Security Council based on Chapter VII UN Charter. ${ }^{31}$

e. proportional means is proportional means which is not excessive from the side of the device and aim respecting the humanitarian law.

${ }^{25}$ Muladi, supra no. 29 at. 6

${ }^{26}$ See, David M. Malone, "Recent Books on International Law", 97 AM. J. INT'L L. 999, 1001, 2003

${ }^{27}$ Rebecca J. Hamilton, supra no. 33, at. 290

${ }^{28}$ Muladi, supra no. 40 at. 4

${ }^{29}$ Int'l Comm'n on Intervention and State Sovereignty (ICISS), The Responsibility to Protect: Report of the International Commission on Intervention and State Sovereignty, International Development Research Centre, Canada, 2001, p. 32

${ }^{30}$ David Scheffer, supra no. 14 , at. 113

${ }^{31}$ Rebecca J. Hamilt, "The Responsibility..., Op.Cit. ,p. 291

${ }^{31}$ Muladi, supra no. 43 , at. 4 
f. reasonable prospect is a reasonable prospect in conducting a military intervention, which means there is a success guarantee to stop the mass atrocities and suffering, and also not to raise a bigger conflict. ${ }^{32}$

If it is difficult to gain the legitimate authority, while the majority of the UN members support the implementation of the intervention, ICISS suggests that the permanent members of the Security Council should be abstained to use the Veto to block the intervention, except if the state concerned has a viral interest regarding the intervention. ${ }^{33}$

\section{Refusal of the R2P principle}

Even though the R2P principle from ICISS is considered comprehensive enough, however, it also receives many rejections, especially worries regarding its implementation. India, China, Brazil, Russia, and South Africa are skeptical of the development of this doctrine. ${ }^{34}$ They argued that the intervention in Libya has given a bad name to R2P. 35

David Vessel stated that indeed there is no international law that legalizes unilateral humanitarian intervention. ${ }^{36}$ Whatever the reason, the third pillar of R2P will violate state sovereignty. The principle of state sovereignty is the core of international law. The key element of this principle is, as recognized since the Westphalia treaty in 1648, legal equality of nations, autonomy and noninterference by other states. ${ }^{37}$ Prohibition of interfering with other states' affairs is also stated in Article 2 section (7) ofthe UN Charter. ${ }^{38}$ The basic element from statehood is state sovereignty, which means a state must be allowed to organize its own matters, including in creating its law for the people. One of the key aspects of state sovereignty is the state's right to stop foreign parties to

${ }^{32}$ Ibid...

${ }^{33}$ Rebecca J. Hamilton, supra no. 42

${ }^{34}$ Jeremy Sarkin, "Is the Responsibility to ProtectAn Accepted Norm in International Law in the postLibya Era?,"Groningen Journal of International Law, Vol. 1 No. 9, 2012, p. 23-24

${ }^{35}$ Ibid...

${ }^{36}$ David Vesel, "The Lonely Pragmatist: Humanitarian Intervention in an Imperfect World", 18 BYU J. PUB. L. 1, 2003, p. 18-19

37 Michael J. Kelly, "Pulling at the Threads of Westphalia: "Involuntary Sovereignty Waiver"? Revolutionary International Legal Theory or Return to Rule by the Great Powers?”, 10 UCLA J. Int'l. L. \& For. Aff. 361, 2005, p. 1364

${ }^{38}$ Nadia Banteka, supra no. 30 
interfere with the government's method of organizing the people. ${ }^{39} \mathrm{~A}$ sovereign government is a government which, in defacto or dejure, is able to gain administrative control towards its own affairs and does not subdue to other state's governments..$^{40}$ Some of the other objections towards the R2P principle according to Gareth Evans are related to its widespread and scope, and the difference of interests among the permanent members of the Security Council. ${ }^{41}$

Therefore, it can be concluded that R2P cannot be implemented appropriately in a situation where interests exist among the permanent member of the Security Council who has a Veto right. Another concern is that the R2P principle will legitimize the tendency of neo-colonialist from developed countries, such as the United States of America's invasion of Iraq as an example.42

The worry is reasonable along with the discourse of expanding the R2P coverage up to the responsibility to prevent security disasters, ${ }^{43}$ especially regardingnuclear power and also preemptive strikes on suspected terrorist targets. ${ }^{44}$

Another skeptical statement is that there is actually no renewal concept in the R2P principle, it only tries to revive Saint Augustine's "Just War" theory in 400s. ${ }^{45}$ Under the doctrine of humanitarian intervention, a state can intervene in other state's affairs when a serious human rights violation occurred and the state, where the violation occurred, is incapable or does not want to overcome the problem. ${ }^{46}$ Humanitarian intervention doctrine, though recognized in classic

${ }^{39}$ Kyle Bagwell, Robert W. Staiger, "National Sovereignty in an Interdependent World", Nat'l Bureau of Econ. Research, Working Paper No. 10249, 2004, available at http:// www.nber.org/papers/w10249, last visited 10 September 2017

${ }^{40}$ Michael Small, supra no. 36, at. 193

${ }^{41}$ Gareth Evans, "Russia and the "Responsibility to Protect", Opinion L.A. Times, Aug, 31, 2008, inhttps://www.latimes.com/la-oe-evans31-2008aug31-story.html

42 Mohammed Ayoob, "Third World Perspectives on Humanitarian Intervention and International Administration”, 10 Global Governance 99, 2014, p. 115

${ }^{43}$ Lee Feinstein, Anne-Marie Slaughter, "A Duty to Prevent”, Foreign Affairs, Vol. 83, No. 1, Jan-Feb, 2004, p. 136

44 Ivo Daalder, James Steinberg, "Preventive War, A Useful Tool", L.A. TIMES, Dec 4, 2005, in latimes.com/archives/la-xpm-2005-dec-04-op-preemptivewar4-story.html

${ }^{45}$ Jeremy I. Levitt, “The Responsibility to Protect: A Beaver Without a Dam?”, 25 MICH. J. INT'L L. 153,2003 , p. 176

${ }^{46}$ David J. Scheffer, "Toward a Modern Doctrine of Humanitarian Intervention", 23 U. Tol. L Rev, 253,1992, p. 264 
international law, has been replaced by a collective security system designed and discussed in Chapter VII of the UN Charter. ${ }^{47}$

\section{Support Towards R2P}

For States which support R2P such as Bosnia Herzegovina, Columbia, France, Gabon, Germany, Nigeria, Portugal, the United Kingdom, and the United States, ${ }^{48}$ the sovereignty principle of state must be re-conceptualized. What is inherent in state sovereignty is about accountability and responsibility to the vulnerable population. ${ }^{49}$ The R2P is not another name of humanitarian intervention. The R2P has three stages. These stages are the responsibility of the states to prevent, react, and rebuild when confronted with mass atrocities. These three stages can be conducted by using many methods, such as education, diplomacy, sanctions, and etc. ${ }^{50}$ The R2P is in line with one of four UN's goals which named as to promote and protect human rights. ${ }^{51}$ The R2P is also in line with the development of International Human rights law which focuses more onthe human rights problem as it becomes the world's center of attention. This is proven by the increase of instruments in International Human Rights law. It is quite unfair to blame the R2P principle in the case of the US's attacks towards Iraq, considering that in this case, there has been a misuse of the R2P principle. If the parameter of R2P is implemented, then clearly the attack cannot be justified legally.

Humanitarian intervention cannot be separated from R2P. R2P has humanity goals and contains the intervention aspect within it. On the other hand, humanitarian intervention cannot be conducted without responsibility. Furthermore, it is aimed to protect the civil society who suffers violation in the territory of the target state. $\mathrm{R} 2 \mathrm{P}$ and humanitarian intervention involve military intervention as the last alternative and in a very exceptional situation. Besides that, both of the matters also face a similar dilemma in regard to sovereignty

47 W. Michael Reisman, "Criteria for the Lawful Use of Force in International Law”, 10 Yale J. Int'l L. 279, 1985, p. 279

48 Jeremy Sarkin, supra No. 49

${ }^{49}$ United Nations World Summit, September, 14-16 2005, 2005 World Summit Outcome, P 139, U.N. Doc. A/60/L.1 (Sept. 15, 2005), p. 138. See also Elizabeth F. Defeis, "The Responsibility to Protect and International Justice”, 10 J. Int'l Bus. \& L. 91, 2011, p. 92

${ }^{50}$ Elizabeth F. Defeis, Ibid...

51 See art.1 UN charter 
versus minority protection. The challenges faced by the R2P principle up until now are still about authority, political will, and operational capacity, which those three actually were not new problems. ${ }^{52}$

The responsibility to prevent is the most important element of R2P. The Secretary-General of the United Nations delivered some recommendation regarding the implementation of the first pillar of R2P:53 a. Giving guarantee of the effective mechanism to manage domestic conflicts; $b$. Protecting the rights of women, the young generation, and minorities as part of the state's society; c. Implementing International Law agreements regarding the Human Rights, International Humanitarian Law, and Law about the refugee, and also Rome Statute about International Criminal Court; d. Involving into the process of acknowledging the $\mathrm{R} 2 \mathrm{P}$ principle which can be integrated into State; e. Attempting to fix the conditions which support responsibility enforcement to protect, such as police officers, military forces, courts, and statute compiler to fix the rule of law and Human Right protection; f. Working together with NonGovernment Organizations (NGOs) and International organizations to facilitate the development of responsibility to protect.

\section{The Implementation of the First Pillar of R2P in Indonesia}

Conflict is a normal matter in human life, but it can be a serious problem when it creates violence. Social violence refers to a physical form or real form of an act which accomplished by a group of people or mass in a certain period of time and a certain place, such as vandalism, murder, marauder, assault, burning, dispute, hostage, and other violent acts. These social violence incidents can be categorized into four major categories: communal violence, separatist violence, state-community violence, andindustrial relations related to violence. ${ }^{54}$

That communal violence is social violence happened between two groups of people or the community. The communal category can be based on ethnicity, religion, social class, politic affiliation, or just different village (living place), etc.

52 S. Neil Macfarlane et. al., "The Responsibility to Protect: Is Anyone Interested in Humanitarian Intervention?", Third World Quarterly, Vol. 25, No. 5, 977, 2004, p. 980

${ }^{53}$ Secretary General of the UN, "Implementing Responsibility to Protect", U.N.Doc. A/63/677, p. 10-14

${ }^{54}$ Mohammad Zulfan Tadjoeddi, supra no. 19, at. p. 2 
The social violence that happened in Maluku, Poso, and Sambas are a few examples of communal violence cases. Communal violence is usually related to ethnic, religion, and local-new comer issues. These three major issues are very difficult to be separated. For example, migrants from Madura who live in Borneo are usually Moslem people, while the local people or Dayak tribe people are usually Christian. When social conflict happened between them, it is difficult to differentiate whether the issue of ethnicity, religion or origin triggered the conflict. Other examples are the bloody conflicts in Maluku, Poso, and Luwu. The conflicting groups in this territory have different religions (Islam and Christian), different ethnic and each of them represents what is called newcomer and local people. Practically, there are no singled-issue conflicts under this sub-category as a communal conflict category. .5

Second, separatist violence is social violence between the state and the society which rooted in the province separatist conflict. It is a movement motivated by the aspiration of some of the people in a certain province to separate themselves from Indonesia as a state. This type of social violence is referring to the conflicts in Aceh and Papua, and as what happened before in east Timor. ${ }^{56}$

In addition, there is state-community violence. It is violence between state and society which is expressing protest and dissatisfaction towards the state institution without separatism motive. For example is the Nipah reservoir incident in Sampang, Madura in 1993 and also the Trisakti students' shooting incident in 1998.

The report from the Human Right National Commission of Indonesia stated that crimes against humanity occurred in several incidents, such as the Tanjung Priok case in 1984; riot of Trisakti and Semanggi in 1997-1998 as the effect of the fall of Soeharto; East Timor case in 1999; and there were at least three incidents in Papua as follows Abepura in 2000, Wasior in 2001, and Wamena in 2003.57 The communal violence is the worst social conflict that happened in Indonesia. The casualty was up to $77 \%$ as the effect of the social conflict, followed by separatist

\footnotetext{
${ }^{55}$ Ibid..., p. 42

${ }^{56}$ Ibid..., p. 27

${ }^{57}$ Suzannah Linton, “Accounting for Atrocities in Indonesia”, 10 SYBIL 199, 2006, p. 199
} 
violence which is up to $22 \% .58$ The dominant issues from communal violence are ethnic, religion and migration which caused two-third of the casualty. In other words, it also contributes around $52 \%$ of the total casualty in social violence. ${ }^{59}$

The previous research concerning social violence patterns can be made as a lesson, so a similar incident will not occur in the future. When human rightsare protected, the rule of law is conducted well, good governance is applied, and mass violence can be prevented. Therefore, the effort of providing and streng thening the rule of law in the areas which are susceptible to Human Right violence must be applied. International organizations and NGOs can give technical assistance for the state which needs it. ${ }^{60}$ Prevention can be done through enforcing the rule of law, giving sanction to the intellectual actor of mass atrocities without discrimination of who is the person and what the position that the person holds in the government. ${ }^{61}$

In the Indonesian context, the effort of R2P Implementation can be found in the preamble of the 1945 Indonesian constitution, which clearly stipulated the government's responsibility to protect all of the individuals and participate in the gaining of world peace. ${ }^{62}$ Furthermore, Implementation of the first pillar of R2P can be found in Law Number 7 of 2012 concerning Social Conflict Management (SCM), followed by Government Regulation No. 2 of 2015 concerning Implementation of Law on SCM.63

Social conflict based on Article 1(1) Law Number 7 of 2012 and Government Regulation Number 2 of 2015 is conflict and/or physical contact with violence between two groups or more which occur in a certain period of time and has a huge impact which causing insecurity and social disintegration. It is disturbing the national stability and hindering national development. Law and Government regulation on SCM does not give further explanation about the definition.

${ }^{58} I d$, p. 31

${ }^{59} I d$, p. $60-61$

${ }^{60}$ Elizabeth F. Defeis, supra no. 65, at. 96

${ }^{61} I d$

${ }^{62}$ ELSAM, "Implementasi Konsep R2P di Indonesia: Prospek atau Tantangan?", last visited 10 September 2017 available at http://elsam.or.id/2017/09/implementasi-konsep-r2p-di-indonesia-prospek-atautantangan/

${ }^{63}$ Conflict Management under Article 1 (2) of Law 7 of 2012 is a series of systematic and planned activities in situations and events both before, during and after conflict that includes conflict prevention, cessation of conflicts and post-conflict recovery 
However, from the terms: "conflict and/or physical contact with violence", "huge impact", "insecurity", "social disintegration", "disturbing the national stability", it can be concluded that types of social violence such as communal violence, separatist violence, state-community violence, and industrial relations related violence as mentioned before should be included in that definition. This is because, when social conflict cannot be overcome, it can spread become social violence even mass atrocities crime that potentially caused insecurity, social disintegration, disturbing national stability and humanity crises. ${ }^{64}$

SCM based on Law Number 7 of 2012 and Government Regulation Number 2 of 2015 covered: Conflict Prevention, Conflict Termination, and Post-conflict Recovery. ${ }^{65}$ Based on the R2P concept, conflict management in the Indonesian law instrument is aligned with the state's responsibility towards the first pillar of R2P, which is to prevent, to re-act and to build. It is confirmed in the common clarification of SCM Law that one of the philosophy of this Law is a form of state'sresponsibility to give protection, progress, enforcement, and fulfillment of human right through the effort of creating a safe, harmonious, peaceful and prosper environment, as a form of the individual right for protection of oneself, family, honor, dignity and personal belonging, and also the right to receive safety and protection from threat of fear. Free from fear is a guarantee towards the right to have a safe, harmonious, peaceful, fair, and prosperous life. ${ }^{66}$ In addition, there is one sociological argument in making this Law that is Indonesia still does not have a certain form of SCM which is comprehensive, integrative, effective, efficient, accountable, transparent, and right on target based on dialogical and peaceful approach. ${ }^{67}$ Conflict Management which exists up until now is sectoral and reactive, moreover, it is still incompatible with the state administration system. ${ }^{68}$

Conflict Prevention based on Law on SCM is being conducted through several efforts, such as maintaining the harmony of society, developing a peaceful

${ }^{64}$ See article 1(1) Law Number 7 of 2012 and Government Regulation Number 2 of 2015

${ }^{65}$ Art 4 Law No 7 of 2012

${ }^{66}$ See general explanation Law Number 7 of 2012, p. 2

${ }^{67}$ General Explanation Law Number 7 of 2012, p. 3

${ }^{68}$ The juridical argument of the issuance of Law 7 of 2012, See General Explanation of Law 7 of 2012, p. 
conflict resolution mechanism, suppress potential conflict, and building a selfwarming system. Handling Conflict in the event of conflict is done through an effort to stop physical violence, confirmation of Conflict status, emergency measures of rescue and victim protection, and/or deployment of military forces. The next efforts of SCM in the post-conflict stage are reconciliation, rehabilitation, and reconstruction. ${ }^{69}$

The analyses toward Law on SCM also its government regulations showed that the provision regarding law enforcement mechanisms is very limited. Both of them do not refer to Law Number 26 of 2000 on Human Rights Court. ${ }^{70}$ Article 34 Government Regulation Number 2 of 2015 only refers to Law on The Police Department of Indonesia, Law on Indonesian Attorney, and Law on Judicial Power, code of penal Procedure (KitabUndang-Undang Hukum Acara Perdata (KUHAP)) hereafter, penal code (Kitab Undang-Undang Hukum Pidana (KUHP)), civil code, and code of Civil Procedure Law no 26 of 200 is very important to be referred by law on SCM because this law granted jurisdiction to human right court for crimes against humanity and genocide, while Acts referred by Law on SCM did not include provisions for the exercise of jurisdiction over genocide, war crimes, torture or crimes against humanity. ${ }^{71}$ According to Suzanna Linton:

"The KUHP contains many provisions on the unlawful taking of life (murder, premeditated murder, manslaughter, etc), for harm against the person (assault, kidnapping, rape) and damage to property. Arbitrary arrest and detention are criminalized, as is an abuse of authority and other crimes committed by State officials. It also contains limited and outdated provisions on sexual assault. There are no provisions on international crimes".72

Furthermore, international crimes such as crimes against humanity and genocide are extra-ordinary crimes. It was not enough to use the standard procedure of ordinary Law (code of penal procedure). ${ }^{73}$ Criminal accountability of perpetrator when social conflict widespread become social violence even mass

${ }^{69}$ General explanation of Law number 7 of 2012

70 Article 34 Government Regulation Number 2 of 2015

${ }^{71}$ Suzannah Linton, supra note no. 80 at 204

${ }^{72} i d$

${ }^{73}$ R. Herlambang Perdana Wiratramanet.al., report of research: "Impact And Implication Of Constitution Court Which Revoked Law On CTR To Law Mechanism And Justice Principle For Victims: Gross Violation On Human Right Resolution”, Constitution Research Institution, Airlangga University, 2007, p. 41 
atrocities crime is very important. It is not sufficient to just take reconstruction, rehabilitation or reconciliation, ${ }^{74}$ which are the main focus of SCM law. Legislators did not think far ahead that social conflict may widespread mass atrocities crime and that Law should be able to overcome up to that stage. Various Law that which are referred by SCM Law for law enforcement does not workwhen mass atrocities crime occurred because those Laws do notintend for law enforcement of mass atrocities crime.

Nowadays, the only law which can be used to enforce the law when mass atrocities crime occurred in Indonesia is Law Number 26 of 2000 on human Right Court $^{75}$, considering that Constitutional Court had revoked the Law Number 27 of 2004 on Commission of Truth and Reconciliation (CTR).

The facts showed that the minimum law enforcement and High impunity culture becomes the other challenge of the implementation of R2P in Indonesia. Certain court decision on the case of gross violation of human rights does not include intellectual actor of such crimes. Those decisions only punished their subordinates. In TanjungPriok case the top Indonesian military officer who was allegedly responsible for the gross human rights violation in Tanjung Priok was never brought to court. Furthermore, the court has failed to find material truth in the 1984 Tanjung Priok incident and have failed also to provide justice for victims of serious human rights violations in Tanjung Priok. ${ }^{76}$ In the Nipah reservoir case, the perpetrators are only subject to the sanction of mutation. Law runs unjustly and is not free from the interventions of the authorities. ${ }^{77}$ In the Abepura case, ${ }^{78}$ National Commission on Human rights (KOMNAS HAM) recommended twentyfive Police and BRIMOB (Riot Police) officers being investigated and prosecuted

\footnotetext{
${ }^{74}$ Rizcky Ramadhan Lapasau, "Pemidanaan Terhadap Pelaku Amuk Massa Tinjauan dari Pasal 55 KUHP (Punishment to Actor ofRiot in the perspective of Article 55 Indonesian Penal Code), Lex et Societatis, Vol. III/No. 10/Nov/20, at. 78 genocide

75 The jurisdiction of human right courtunder law number 26 of 2000 are crimes against humanity and

76 Supra note 79

77 Supra note 77

${ }^{78}$ This case started when unknown persons killing two policemen and a security guard, and set fire to shopsat the Abepura market at 7 December 2000. In response, a group of riot police (Brimob) committed repression against studentsat Ninmin dormitory and conducted similar operations in four other student residential areas in the Jayapura area, National commission on Human rights (KOMNAS HAM) in its report on 20 April 2001 confirmed that there was crimes against humanity at Abepura. Torture, summary executions, assault on the basis of gender, race and religion, arbitrary detention and violation of property rights had been committed in Abepura as part of a systematic and widespread attack. See Suzannah Linton, supra note 94 at 209
} 
by the Attorney General under the Law on Human Rights Courts. However, only two of the recommended twenty-five had been tried for crimes against humanity before the Human Rights Court at Makassar in 2004. Finally, the accused were acquitted of the crimes against humanity charges laid against them, and the claim of compensation filed by the victims was also dismissed. ${ }^{79}$

These conditions are certainly potentially causing dissatisfaction for both victims and communities that can trigger mass atrocities crime. According to Ignas Kleiden no changes in Indonesia before and after the reformation era. 80 Political stability takes precedence over efforts to uphold law and justice. For example, it is still very difficult to hold the accountability of former or who are still active as members of the Indonesian army forces against human rights violations in the past such as in the case 1965, Aceh, Tanjung Priok, May 1998, etc. Those people even still have a very strategic political position at the national level, so that efforts to take legal action will be interpreted as an act of destabilizing national political stability. It is assumed will produce strong political resistance from military groups. ${ }^{81}$

The minimum law enforcement in law and government regulation on SCM becomes a huge question because one of the forms of social conflict management is prevention and settlement social conflict which running well. Prevention and settlement of mass atrocities crime can be conducted by enforcing the law well, which is giving justice to all parties, including giving sanction to all perpetrators of mass atrocities, without discrimination of who is the person and what the position that the person holds in the government. ${ }^{82}$ The minimum law enforcement arrangements in Law and Government Regulation on SCM seems to strengthen the high impunity culture, and also the lack of politic willingness to conduct the first pillar of R2P well. This conditions potentially triggers other violence in the society, because the perpetrator feels safe to conduct that violence.

\footnotetext{
${ }^{79}$ id at 104

${ }^{80}$ The reformation era began since the fall of Soeharto, who has been in power for 32 years as president of Indonesia (1966-1998)

${ }^{81}$ Daniel Hutagalung, "Negara danPelanggaran HAM Masa Lalu:TuntutanPertanggungjawaban versus Impunitas" (State and human right violation in the past: claim of responsibility versus impunity), Dignitas, Vol. 3, No. 1, 2005, p. 6

${ }^{82} I d$
} 
Regardless of having some flaw in Law Number 26 of 2000, the fact is only this law which owned by the Indonesian Government to enforce the law when mass atrocities crime happens, so Law and Government Regulation on SCM should refer to Law Number 26 of 2000 in its law enforcement. Another alternative is the Law and Government Regulation on SCM is self-managing on how comprehensive law enforcement should be when social conflict is causing the mass atrocities crime. If the aim of the Law is to create a certain policy of Conflict Management which is comprehensive, integrative, effective, efficient, accountable, transparent, and right on target, then the enforcement of the law must become a priority when a social conflict becomes mass atrocities crime.

Even though in post-conflict management there are reconciliation, rehabilitation, and reconstruction under SCM law, however, The minimum law enforcement arrangements in SCM law become the challenges of the implementation of the first pillar of R2P in Indonesia. The social conflict which widespread into mass atrocities crime will be difficult to overcome when law enforcement provision is very minimum. Law enforcement should be conducted well. Mass atrocities crime cannot be settled only by Law on Attorney, Criminal Code, and Civil Code, considering that mass atrocities crime is an extra-ordinary crime, so it needs extra-ordinary law enforcement as well.

Furthermore, the lack of knowledge about R2P, the impartiality of government towards some majority groups, makesthe implementation of the first pillar of R2P more difficult. 83 To assure that the R2P values can be implemented well in Indonesia, still needed legal reform and increased public awareness and capacityof the importance of R2P applied in Indonesiaon the basis of the constitutionality of R2P values in the philosophy of the Indonesian nation.

\section{Conclusion}

1. Regardless of having some flaws in its development, R2P has gained more support from International society. R2P principle is more complete than the humanitarian intervention principle. Having three pillars, three sections of 
implementation and six parameters thresh hold situation, R2P is ready to be conducted.

2. The implementation of the first pillar of R2P in Indonesia has not been conducted well. The challenges are minimum law enforcement arrangements on SCM law especially when social conflict widespread becomes mass atrocities crime, the high impunity culture, and also the lack of politic willingness to conduct the first pillar of R2P well. The lack of knowledge about $\mathrm{R} 2 \mathrm{P}$, the impartiality of government towards some majority groups, makesthe implementation of the first pillar of R2P more difficult. Furthermore, the revocation of Law number 27 of 2004 on CTR by Constitutional Court support legitimizes impunity culture and potentially causes new social conflict in the society which also potentially widespread become mass atrocities crime.

\section{Bibliography}

\section{Books}

Franck, Thomas M, International Change in the Law of Humanitarian Intervention" in JL Hobzgrefe\& Robert O Keohane (eds.), Humanitarian Intervention: Ethical, Legal and Political Dilemmas, University Pres, Cambridge, 2003.

Hehir, Aidan, "The Responsibility to Protect and International Law", in Philip Cunliffe (ed.), Critical Perspectives on the Responsibility to Protect: Interrogating Theory, Practice, Martinus Nijhoff, 2011.

Sulistyo, Hermawan, PaluArit di LadangTebu: Sejarah Pembantaian Massal yang Terlupakan, Jombang-Kediri 1965-66, Gramedia, Jakarta, 2000.

Susetiawan, Konflik Sosial, Kajian Sosiologis Hubungan Buruh, Perusahaan dan Negara di Indonesia, Pustaka Pelajar, Yogyakarta, 2000.

Susan, N, Sosiologi Konflik dan Isu -Isu Konflik Kontemporer, Prenada Media Group, Jakarta, 2009.

\section{Journals, Articles, Paper}

Ayoob, Mohammed, "Third World Perspectives on Humanitarian Intervention and International Administration", 10 Global Governance 99, 2014.

Banteka, Nadia, "Dangerous Liaisons: responsibility to Protect and reform of The Un Security Council", 54 Colum. J. Transnat'l L, 382, 2016.

Djundjunan, Bebeb A.K., Wirakara, Rizal, "The Responsibility to Protect Dalam Perspektif Hukum", Opinion juris, Volume 01, Oktober 2009 
Bellamy, Alex J., "Responsibility to Protect or Trojan Horse? The Crisis in Darfur and umanitarian Intervention After Iraq", Ethics EInt'LAff, Summer, 31, 2005.

Daalder, Ivo \& James Steinberg, "Preventive War, A Useful Tool", L.A. TIMES, Dec 4, 2005.

Defeis, Elizabeth F., "The Responsibility to Protect and International Justice", $10 \mathrm{~J}$. Int'l Bus. E L. 91, 2011.

Feinstein, Lee \& Anne-Marie Slaughter, "A Duty to Prevent", Foreign Affairs, Vol.83, No.1, Jan-Feb, 2004.

Hamilton, Rebecca J., "The Responsibility to Protect: From Document to DoctrineBut What of Implementation?, 19 Harv. Hum. Rts. J. 289, 2006.

Hutagalung, Daniel, "Negara dan Pelanggaran HAM Masa Lalu: Tuntutan Pertanggungjawaban versus Impunitas" (State and human right violation in the past: claim of responsibility versus impunity), Dignitas, Vol. 3, No. $1,2005$.

Kelly, Michael J., “Pulling at the Threads of Westphalia: “Involuntary Sovereignty Waiver"? Revolutionary International Legal Theory or Return to Rule by the Great Powers?",10 UCLA J. Int'l. L. E For. Aff. 361, 2005.

Koskenniemi, Martti, "The Police in the Temple Order, Justice, and the UN: A Dialectical View", 6 Eur. J. Int'L law 1, 1995.

Linton, Suzannah, "Accounting for Atrocities in Indonesia", 10 SYBIL 199, 2006.

Levitt, Jeremy I., “The Responsibility to Protect: A Beaver Without a Dam?”, 25 MICH. J. INT'L L. 153, 2003.

Macfarlane, S. Neil et.al.,"The Responsibility to Protect: Is Anyone Interested in Humanitarian Intervention?", Third World Quarterly, Vol. 25, No. 5, 977, 2004.

Mainstreaming the Responsibility to Protect Southeast Asia: Pathway toward Caring ASEAN Community, Report of the High Level Advisory Panel on the Responsibility to Protect in Southeast Asia, Presented at the United Nations, New York, September 9th 2014.

Malone, David M., “Recent Books on International Law”, 97 AM. J. INT'L L. 999, 1001, 2003.

Muladi, "Hakekat Norma R2P atau Responsibility to Protect danAmbang Batas Justifikasinya", article on Upgrading Recent Issues of International Law doctrine, held by Association of lecturer of international law cooperate with Faculty of Law, UniversitasDiponegoro, Semarang, 20-21 May, 2011.

Payandeh, Mehrdad, "With Great Power Comes Great Responsibility? The Concept of the Responsibility to Protect Within the Process of International Lawmaking", 35 Yale J. Int'l L. 469, 2010. 
Rahayu, "Eksistensiprinsip Responsibility to protect dalam Hukum Internasional", article in Upgrading Recent Issues of International Law Doctrine, held by Association of Lecturer of International Law Cooperate With Law Faculty, Universitas Diponegoro, Semarang, 20-21 Mei 2011.

Reisman, W. Michael, "Criteria for the Lawful Use of Force in International Law", 10 Yale J. Int'l L. 279, 1985.

Sarkin, Jeremy, "Is the Responsibility to Protect An Accepted Norm in International Law in the post-Libya Era?",Groningen Journal of International Law, Vol. 1 No. 9, 2012.

Scheffer, David J., "Toward a Modern Doctrine of Humanitarian Intervention", 23 U. Tol. L Rev, 253, 1992.

Scheffer, David, "Atrocities Crimes Framing the Responsibility to Protect", 40 Case W. Res. J. Int'l L. 111, 2007-2008.

Small, Michael, "An Analysis of the Responsibility to Protect Program in Light of the Conflict in Syria", 13 Wash. U. Global Stud. L. Rev. 179, 2014.

St. Aisyah BM, "Konflik Sosial Dalam Hubungan Antar Umat Beragama", Jurnal Dakwah Tabligh, Vol. 15, No. 2, December 2014.

David, "The Lonely Pragmatist: Humanitarian Intervention in an Imperfect World", 18 BYU J. PUB. L. 1, 2003.

News, Article from Internet, Thesis

Bagwell, Kyle \& Robert W. Staiger, "National Sovereignty in an Interdependent World", Nat'l Bureau of Econ. Research, Working Paper No. 10249, 2004, available at http:// www.nber.org/papers/w10249

Gareth Evans, "Russia and the "Responsibility to Protect", Opinion L.A. Times, Aug, 31, 2008, in https://www.latimes.com/la-oe-evans31-2008aug31story.html

ELSAM, "Implementasi Konsep R2P di Indonesia: Prospekatau Tantangan, available at http://elsam.or.id/2017/09/implementasi-konsep-r2p-diindonesia-prospek-atau-tantangan/

Lapasau, Rizcky Ramadhan "Pemidanaan Terhadap Pelaku Amuk Massa Tinjauan dari Pasal 55 KUHP (Punishment to Actor of Riot in the perspective of Article 55 Indonesian Penal Code), Lex et Societatis, Vol. III/No. 10/Nov/20

Mohammad Zulfan Tadjoeddi, "Anatomy of Social Violence in the Transition Context: Case of Indonesia, 1990-2001", working paper: 02 / 01-1, United Nations Support Facility for Indonesian Recovery (UNSFIR), 2002, available at http://www.conflictrecovery.org/bin/ZulfanAnatomi_kekerasan_sosial.pdf 
"Responsibility to Protect: Informasi tentang Prinsip ini dan Langkah-langkah Implementasi", available at http://www.responsibilitytoprotect.org/ R2P_basic_info_Bahasa.pdf

\section{Perundang-undangan}

Undang-Undang Nomor 7 Tahun 2012 tentang Penanganan Konflik Sosial

Peraturan Pemerintah Nomor 2 Tahun 2015 tentang Peraturan Pelaksanaan Undang-Undang Nomor 7 Tahun 2012. 